DOI: $10.1515 / \mathrm{rpp}-2015-0054$

$\mathrm{PhD}$ in Pedagogical Sciences, Associate Professor, IRYNA LYTOVCHENKO National Technical University of Ukraine "Kyiv Polytechnic Institute" Address: 37 Peremohy Ave., Kyiv, 03056, Ukraine E-mail: irinalyt@ukr.net

\title{
ORIGINS AND FORMATION OF CORPORATE EDUCATION IN THE USA
}

\begin{abstract}
The article analyzes the process of formation and development of corporate education in the USA in the first half of the twentieth century. It has been determined that the main prerequisites for the development of corporate education in the USA in the first half of the twentieth century were historical, socio-economic, political factors and advances in scientific research including: the rapid growth of the US economy in the twentieth century; dissemination of scientific and technological progress and constant introduction of new technologies in the workplace; a national policy of "welfarism"; scientific works of R. Kelly "Training industrial workers" and D. Morris "Employee training: A study of education and training departments in various corporations", which contained the first complex researches on training in industry, substantiated the necessity and prospects of this study, analyzed corporate programs of that time, the ideas on scientific management of F. Taylor, F. Gilbreth and $S$. Thompson, which had a major impact on all business areas. It has been found out that corporate education was the result of evolution of apprenticeship, the oldest and most traditional form of vocational training in the United States. By 1920s a new concept of modern education had been formed in the workplace which had its philosophical foundations, educational programs, technologies, system of providing services and organizational structure. In the period between the First and Second World Wars a new vision of learning at the workplace arose, new teaching methods were developed different from those used in traditional educational institutions; understanding came that the dissemination of knowledge within the whole community would contribute to building a democratic society.

Key words: corporate education, educational programs, apprenticeship, workplace learning, corporate school.
\end{abstract}

\section{INTRODUCTION}

The competitiveness of modern enterprises in the period of transition to "knowledge economy" depends on the level of professional competence of their employees. In this context, a special role is attributed to continuous training of specialists in accordance with the requirements of high-tech manufacture, including corporate education aimed at the needs of enterprises in competitive workers. In this respect, of current interest is the study and implementation of best practices of foreign countries with high levels of socioeconomic development, one of which is the United States, where this form of education has a long history and rich traditions.

THE AIM OF THE STUDY

With this in mind, the purpose of our study is to analyze the formation and development of corporate education in the USA in the first half of the twentieth century.

THEORETICAL FRAMEWORK AND RESEARCH METHODS

The study of common problems of learning, different aspects of modern education policy, training of production personnel in economically developed countries have been 
analyzed in works of such Ukrainian scientists as N. Abashkina, N. Bidyuk, T. Desyatov, L. Khomich, V. Kudin, N. Lavrychenko, O. Matvienko, O. Ogiienko, N. Pazyura, L. Pukhovska, A. Sbruyeva and others. Features of corporate education were the subject of interdisciplinary research of foreign scholars in such fields as economics, management and marketing (C. Argyris, O. Berezkina, J. Brown, R. Cyert, G. Duguid, P. Huber, Y. Malakhov, I. Malychenko, J. March, R. Nelson, I. Nonaka, P. Senge, S. Sycheva, I. Sovyk, S. Winter), education (V. Kaganov, R. Silkin, V. Skarha, V. Zaryhin), psychology (O. Dubinenkova, V. Soroka, P. Trifonova), sociology (Y. Karaman, T. Radayev) and others.

From the methodological perspective, the research was based on interdisciplinary and systematic approaches. Thus, we used a set of interrelated research methods: comparative, structural, systemic-functional analysis, comparison and synthesis which are necessary to study works of scientists, official documents and regulations, empirical data.

\section{RESULTS}

The analysis of scientific sources on the issue of corporate education gives grounds for asserting that it is the result of evolution of apprenticeship, the oldest and most traditional form of vocational training in the United States borrowed from the British Empire. Under American law, persons over the age of 16 can be trained in the system of apprenticeship. Training takes place in areas such as trade, profession or business and is based on a contract between the student and the employer (Cremin, 1988).

However, as L. Cremin states, along with official forms of apprenticeship in business and industry, informal forms have always existed where workers were trained to perform new jobs with the help of other workers or supervisors (Cremin, 1988). Apprentices usually were either newcomers in the company, or those who were promoted and had to take on new responsibilities at work. The study was carried out in different ways. For example, an apprentice attained skills through trial and error or by asking questions to their colleagues. Also, an apprentice could be taught from an experienced colleague whom he could imitate and ask questions. Besides a student could study under a supervisor who guided him in his work. There was also a form of apprenticeship, in which systematic staff training was carried out in a special unit of the enterprise where a trainee had to perform a kind of work before doing it at the workplace. Finally, the most highly organized form of apprenticeship was "training departments", special units of the company responsible for the implementation of systematic training, where employees were regularly trained.

The results of our scientific research give reason to believe that it is from these forms of apprenticeship in the early twentieth century the following three main forms of corporate education were developed: workplace learning, training centers and corporate universities as the most complex and advanced form of modern corporate education not only in the USA but worldwide. There is no agreement among scientists about what kind of event should be considered the beginning of corporate education in the United States, but it is reasonable to believe that it is the further development and improvement of the abovementioned forms of apprenticeship that became the basis for the powerful new branch of education in this country.

However, in the late nineteenth, and especially at the beginning of the twentieth century, there were certain very important events in the history of corporate education. First of all it is the establishment of Hoe Company School in 1872 and National Association of Corporate Schools (NACS) in 1913. As L. Cremin states, from the very beginning, the curricula of the first corporate schools were distinguished by diversity, adaptability, practical orientation and specific learning technologies (Cremin, 1988). 
By the 1920-s, a new conceptual vision of modern education in the workplace had emerged. It was distinguished by its philosophical foundation, educational programs, learning technologies, service delivery and organizational structure (Kelly, 1920; Morris, 1921). There were certain socio-economic factors and advances in research that led to the emergence of corporate educational programs in this country. One of the main factors that led to the need for continuous professional education of employees in spheres of manufacture and services was the rapid growth of the US economy in the twentieth century, dissemination of scientific and technological progress and constant introduction of new technologies in the workplace. With the rise in complexity of technology and professional standards the importance of learning steadily increased.

The first comprehensive research into the sphere of corporate education was the monograph of R. Kelly "Training industrial workers" (1920), in which he substantiates the necessity and expresses belief in great prospects of such training. He stresses that each employee needs training, and the employer and society are interested in satisfying this need. Without education workers can not reach their full potential, the efficiency of work suffers and the socio-economic progress is delayed (Kelly, 1920). Balanced corporate programs provided training and adaptation of new employees, training and retraining for career growth, improvement of performance of professional duties and increase of work efficiency.

Corporations were interested not only in the development of technical skills, but also in the intellectual growth of the employees. This is evidenced by the results of the first comprehensive study of corporate programs done in the work of J. Morris, "Employee training: A study of education and training departments in various corporations" (Morris, 1921). Thus, analyzing the products of Westinghouse Electric and Manufacturing Company, one of the largest production companies whose programs were considered the best examples of corporate programs, D. Morris stresses that in addition to skills "an immense amount of initiating intelligence must be constantly introduced in inventing and improving both the products and also their means of production" (Morris, 1921). Engineers, technicians and mechanics effectively controlled the equipment and machines due to differentiated training provided by the company educational division responsible for the development of technical skills and intellectual abilities of workers (Morris, 1921).

To train the employees the corporation used internal and external educational programs. Internal programs included apprenticeship, workplace learning and corporate schools that were established in large corporations. According to L. Cremin, the first such institutions were Ford Motor Company Trade School, founded in 1916, Westinghouse Technical Night School and General Motors Institute of Technology (Cremin, 1988). External programs were provided by evening schools for general education. Joint programs were also established. Thus, the American Banking Institute, founded in 1900, offered courses for bank employees. Insurance Institute of America, established in 1909, started such programs in 1924. Correspondence study also gained wide popularity in corporate training.

Another important impact on the development of corporate educational programs was provided by the ideas on scientific management of Fr. Taylor, Fr. Gilbreth and S. Thompson, which influenced all business areas. In the light of the implementation of these ideas education was considered an important means of improving efficiency. The National Association of Corporate Schools indicated that corporations were increasingly aware of the importance of education for the effective management and the corporate school underwent sufficient testing as a method of continuous enhancement of efficiency and an important factor in the development of industry (Cremin, 1988). 
In the early twentieth century, many companies that became members of NACS first set up such schools. A typical program was established in 1897 by a magnate, owner of a department store John Wanamaker which he called John Wanamaker Commercial Institute. He claimed that the Institute, organized as part of the Philadelphia department store, was a school of practicing methods of business management "giving daily opportunities to obtain a working education in the arts and sciences of commerce and trade" (Cremin, 1988). School curriculum included reading, writing, arithmetic, English, spelling, commercial geography, commercial law and methods of business practices. Faculty teaching staff consisted of twenty-four members, some of whom were employees of the store, the rest Philadelphia school teachers. New employees studied at school in the morning, twice a week. More experienced workers had two classes a week in the evening, and after school ate dinner in the cafeteria department store. Boys and girls were divided in separate groups where they were taught "discipline, organization, precision and obedience" as also "health lessons of muscular training that give bodily strength without which successful mental work is impossible" (Cremin, 1988). J. Wanamaker education program was extremely profitable. According to L. Cremin, "unintelligent and wasteful labor has lessened", while cooperation and mutual assistance grew, knowledge about products, their production, distribution and use expanded, new principles of control, management and organization were developed (Cremin, 1988).

Another socioeconomic factor that influenced the development of educational programs in the workplace during and after World War I was a national policy for "welfarism" (Cremin, 1988). In all sectors of industry across the country, workers were provided with various services to make them more loyal to their companies and distract from the protests that were organized by trade unions. One of the main services was education, directed not only to the development of technical skills, but also to the advancement of Americanization, formation of skills of building stable family relationships and having more rewarding recreation. Companies made substantial investments into local public schools so that their employees' children could get a better general education. They also sponsored homemaking classes, sewing courses, instruction in English and civics for their employees and their families. In addition the company organized libraries and printed periodicals that wrote about the daily life of the company and contained messages and materials intended to unify so-called company family. Training has become an integral part of professional activity at the end of the First World War. The first nationwide conference of personnel managers was held in 1916, and soon, in 1918 the National Association of Employment Managers was founded (Jacoby, 1985). In 1922 the National Association of Corporate Schools and the National Association of Employment Managers merged and formed the National Personnel Association, which a year later turned into the American Management Association (Peffer, 1932).

Workplace learning took into account the lessons of wartime education programs: individual approach to learning was applied, particular importance was attributed to acquisition of practical skills and results of the study, the training courses were divided into modules, programs were based on research of specific characteristics of various occupations and requirements to workers (Neumann, 1979). After the war, leaders who designed and managed training programs for military personnel in war time now used their military experience in workplace learning, focusing on testing the results of the study at workplace, using methods of military training in the apprenticeship system and establishing evaluation criteria.

In the period between the First and Second World Wars the realization came that employees themselves could assess training programs and select the ones that attracted them. There were new ideas and a new vision of education, and given the fact that a 
business organization was now a new, unique training platform, new methods of teaching, different from those in the traditional educational institutions, were developed. New training programs for supervisors and managers were designed, foremen's clubs were founded. In the period from 1923 to 1936 Purdue University trained ten thousand foremen from 616 companies in eighty-seven cities (Graebner, 1987). The National Association of Foremen was founded in 1925. Before the Second World War a democratic system of education was formed as a whole. It was based on the ideas of progressive education and new social psychology. Work in small groups, group discussions, training under the guidance of leaders were used. It became obvious that workers' awareness of their duties at workplace would lead to the spread of knowledge within the entire local community and contribute to building a democratic society.

\section{CONCLUSIONS}

Thus, we can conclude that:

- the main prerequisites for the development of corporate education in the USA in the first half of the twentieth century were historical, socio-economic, political factors and advances in scientific research including: the rapid growth of the US economy in the twentieth century, dissemination of scientific and technological progress and the constant introduction of new technologies in the workplace, the national policy of "welfarism", scientific works of R. Kelly D. Morris, the ideas on scientific management of Fr. Taylor, Fr. Gilbreth and S. Thompson, which had a major impact on all business areas;

- corporate education is the result of evolution of apprenticeship, the oldest and most traditional form of vocational training in the United States;

- by the 1920-s, a new concept of workplace learning had been formed which had its philosophical foundations, educational programs, learning technologies, system of service delivery and organizational structure;

- a new vision of workplace learning arose in the period between the First and Second World Wars, new learning methods different from those used in traditional educational institutions were developed, understanding came that the dissemination of knowledge within the local community could contribute to building a democratic society.

Among perspectives for further researches into different aspects of history of corporate education in the United States of America may be the study of historical development of the corporate university as a most complex and advanced form of corporate education in this country.

\section{REFERENCES}

1. Cremin, L. (1988). American education: The metropolitan experience 1876-1980. New York, Cambridge, Philadelphia, San Francisco, Washington, London, Mexico City, Sao Paulo, Singapore, Sydney : Harper \& Row Publishers, $781 \mathrm{p}$.

2. Graebner, W. (1987). The engineering of consent: Democracy and authority in twentieth-century America. Madison, Wis. : University of Wisconsin Press, xi, $262 \mathrm{p}$.

3. Jacoby, S. (1985). Employing bureaucracy: Managers, unions, and the transformation of work in American industry, 1900 - 1945. New York: Columbia University Press, 377 p.

4. Kelly, R. (1920). Training industrial workers. New York : Ronald Press, XXI, 437 p.

5. Morris, J. (1921). Employee training: A study of education and training departments in various corporations. New York : McGraw-Hill, XXIII, $311 \mathrm{p}$.

6. Neumann, W. (1979). Educational responses to the concern for proficiency. In: Grant, G. (Ed.) On competence: A critical analysis of competence-based reforms in higher education. San Francisco: Jossey-Bass Publishers, pp. 66-94.

7. Peffer, N. (1932). Educational experiments in industry. New York: Macmillan Co., 207 p. 